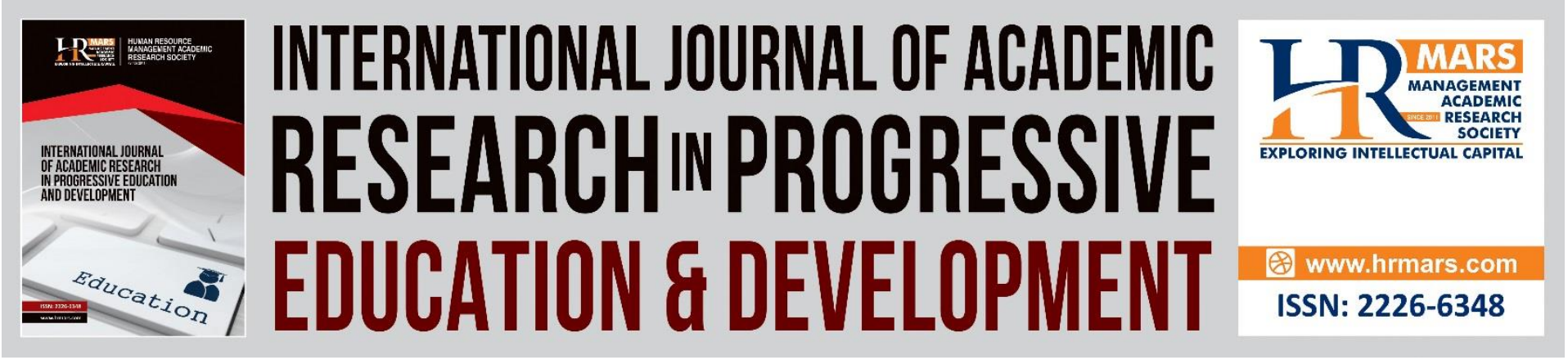

\title{
Legal Knowledge and Awareness of The School Teachers on The Educational Rights of Children with Special Needs in Malaysia
}

\section{Nur Ezan Rahmat, Anida Mahmood, Muhammad Fikri Othman}

To Link this Article: http://dx.doi.org/10.6007/IJARPED/v10-i3/11099

DOI:10.6007/IJARPED/v10-i3/11099

Received: 05 June 2021, Revised: 09 July 2021, Accepted: 27 July 2021

Published Online: 26 August 2021

In-Text Citation: (Rahmat et al., 2021)

To Cite this Article: Rahmat, N. E., Mahmood, A., \& Othman, M. F. (2021). Legal Knowledge and Awareness of The School Teachers on The Educational Rights of Children with Special Needs in Malaysia. International Journal of Academic Research in Progressive Education and Development, 10(3), 579-590.

Copyright: (C) 2021 The Author(s)

Published by Human Resource Management Academic Research Society (www.hrmars.com)

This article is published under the Creative Commons Attribution (CC BY 4.0) license. Anyone may reproduce, distribute, translate and create derivative works of this article (for both commercial and non-commercial purposes), subject to full attribution to the original publication and authors. The full terms of this license may be seen at: http://creativecommons.org/licences/by/4.0/legalcode

Vol. 10(3) 2021, Pg. $579-590$

http://hrmars.com/index.php/pages/detail/IJARPED

JOURNAL HOMEPAGE

Full Terms \& Conditions of access and use can be found at http://hrmars.com/index.php/pages/detail/publication-ethics 


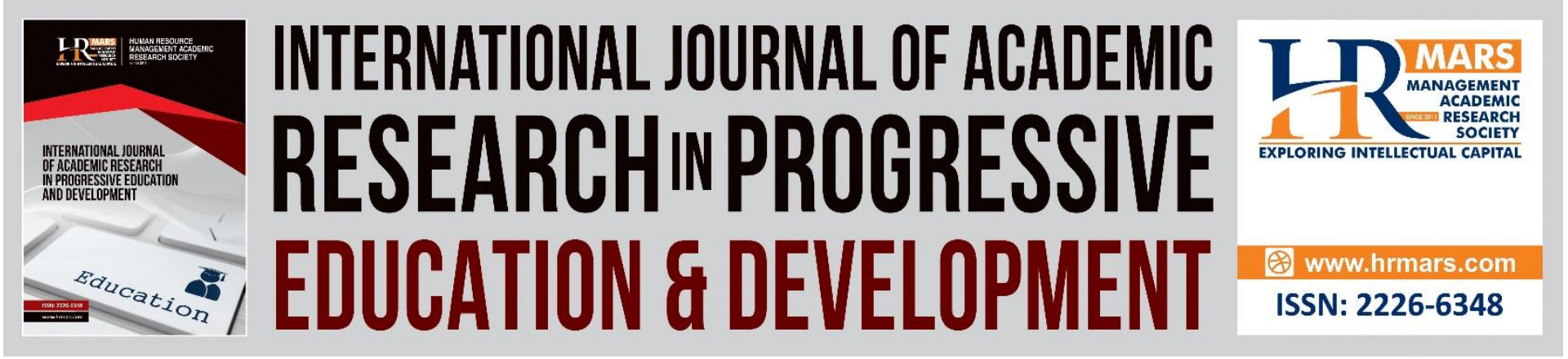

\title{
Legal Knowledge and Awareness of The School Teachers on The Educational Rights of Children with Special Needs in Malaysia
}

\author{
Nur Ezan Rahmat, Anida Mahmood, Muhammad Fikri Othman \\ Faculty of Law, Universiti Teknologi Mara (UiTM) Shah Alam, Selangor, Malaysia \\ Email: nurezanrahmat@gmail.com
}

\begin{abstract}
Section 28 of Persons with Disabilities Act 2008 provides children with disabilities shall not be excluded from pre-school, primary and secondary schools on basis of their disabilities and should be treated equally with children without disabilities. Since they are disabled children, they need special treatment, special tools and facilities to accommodate their education and therefore they have been categorized as children with special needs. Ministry of Education and the Ministry of Women, Family and Community Development are responsible for the education for these children. To provide education for children with special needs efficiently, the teachers must have legal knowledge and awareness of these children educational rights. Therefore, this research has been conducted to study the level of legal knowledge and awareness of the school teachers on the educational rights of children with special needs in Malaysia. This research adopts a mixed-method approach which involves the collection, analysis, and integration of qualitative and quantitative data. Questionnaires have been distributed to the teachers of the Integrated Special Education Program to examine their legal knowledge and awareness on the educational rights of children with special needs. Respondents have been selected randomly from several primary and secondary government schools in Selangor. The analysis of variables is categorized into demographic characteristics of the teachers and their knowledge and awareness on the rights of children with special needs on therapy, facilities, and special module. Result of this study reveals that the teachers have a moderate knowledge of the educational rights of children with special needs, but they are very aware of these children educational rights.
\end{abstract}

Keywords: Educational Rights, Children with Special Needs, Teacher, Knowledge, Awareness

\section{Introduction}

According to the Universal Declaration of Human Rights, every child has the right toward education and this right has been reaffirmed by the World Declaration on Education for All. Hence, children with special needs also are entitle towards education. Children with special needs according to the Malaysian Education Blueprint 2013-2025 are children with visual impairment, hearing impairment, speech difficulties, physical difficulties, multiple disabilities and learning disabilities. Furthermore, Section 2 of Persons with Disabilities Act 2008 defines 
persons with disabilities as the person who have long-term physical, mental intellectual or sensory impairments, which in interaction with various barriers may hinder their full and participation in society. The study has consistently emphasis on the needs and importance of education for children with special needs. Turnbull et al (1995); Heward (2000) states that children with special needs have a right to education and that school has the legal responsibility to provide equal educational opportunities for children with disabilities. In ensuring the right of education to every child, teachers need to have knowledge on how to protect and promote students' (human) right. To do so, teachers need to know the law (legal provisions and legal protections of the teaching profession) as the medium to advocate students right successfully (Pillay, 2014). Teachers are the custodian of the students' right. In protecting such right to children with special needs, Farrell (2001) specifically addresses three key elements related to the education of school children with special needs; the role of school providers and categories in special education; the impact of legislation on assessment procedures; and developments in inclusive education.

Since the number of children with special needs increasing, the teacher should have a working and sufficient knowledge of special education law. This due to the teacher is always the first person who identifies the children in needs of special education. Various studies have been conducted at the international level to determine the teachers' legal knowledge on the law and policies governing special education for children with special needs. Eni and Arit (2016) investigate knowledge of education law and breach of human rights amongst secondary school personnel and teachers in Nigeria. 92 respondents participated in the survey. The survey reveals that respondents' secondary school personnel do not possess knowledge of the education law and they also have violated students' rights in school. The study suggests that educational institutions should incorporate education law as a minimum curriculum requirement. Pillay (2014) in his dissertation investigates to what extent awareness and knowledge of law influences teachers' practice. Education laws in this context are the education modules, the constitution and the South African Schools Act. The study reveals that the respondents possess reasonable knowledge on law and policies that regulate education in South Africa. They did not have in-depth knowledge or understanding of the law and policies that govern the education system in Africa. It was found out that the knowledge acquired was as a result of their experience and not because of the formal training in education law.

Whilst Eni and Pillay focus on knowledge of teachers in education law in general, Kurniawati, et al (2017) examines the schoolteachers' attitudes on special educational needs, teaching strategies and training programme. Special educational needs refer to children who have learning problems or disabilities that make it harder for them to learn than most children of the same age. (The Salamanca Statement, 1994). The finding of the study indicates positive attitudes from the teachers on the importance of special education needs and the training programme designed. Earlier, Glidewell (2012) conducts a survey for teachers in Arkansas to test their knowledge and understanding of the special education law. Glidewell argues that all educators must know and understand the law and regulation governing public education, particularly special education for children with special needs. Through the survey, the participants' responses were evaluated to determine the extent of their knowledge. Participation was voluntary and conducted during school hours. The results of the study concluded that respondent teachers have a general knowledge of special education law but may not be aware of any changes in the law. 
Likewise, O'Connor, et. al (2016) state that schoolteachers must have knowledge on special education law that impact students' eligibility for services. The special education law referred to are The Individuals with Disabilities Education Act Insights into Learning Disabilities (IDEA) and section 504 of the Rehabilitation Act (1973). A survey was also conducted in measuring the level of knowledge amongst the teachers where the respondents were 58 kindergarten teachers who enrolled in in graduate classes at a private university in the New York City to obtain master's degree in literacy. The results reveal that the respondents are lacking some essential information about IDEA and possess limited knowledge of provisions covered by Section 504.

\section{Malaysian Education Programmes for Children with Disabilities}

There are three main education programmes for special education for children with special needs in Malaysia namely Special Education Programme, Special Education Integration Programme and Inclusive Education Programme. These three special education programmes differ from each other and managed by the Ministry of Education. According to Nasir and Efendi (2016), Special Education Programme is an education system which caters the education for children with special needs including disabled children, gifted and other marginalised children. The children with special needs will be placed in special schools based on their disabilities such as schools for visual impairment and hearing impairment. The progress of special education in Malaysia has been divided into four stages which are before and during the early colonial period (before 1900), pre-independence (1900-1957), postindependence (1957-1990) and modern Malaysia (1990 to the present) (Lee \& Low, 2014) The second type of special education programme is Special Education Integration Programme. Compared to Special Education Programme, this integration programme placed children with special needs in special classes in mainstream schools (Mottan, 2015). By having this programme, children with special needs are able to develop their social and communication skill effectively since they learnt in normal learning and least restrictive environment. Special Education Integration Programme allows children with special needs to participate in school's activities together with normal students and therefore improve their social integration with others (Omar \& Sulaiman, 2018)

On the other hand, Teng (2016) stated Inclusive Education is an education programme whereby children with special needs to be placed in the same classes with normal students and general education curriculum will be provided to them. This education programme is introduced to give maximum interaction between children with special needs and normal students (Teng, 2016). Garis panduan Program Pendidikan Inklusif Murid Berkeperluan Khas (Edisi Percubaan) has been used a guideline for their enrolment. This guideline consists of students' criteria, students' placement, teacher, teaching and learning and assessment.

\section{Laws and Policies Relating to Special Education for Children with Disabilities in Malaysia}

According to Baqutayan and Khalil (2016), there are a few laws and policies relating to special education for children with disabilities in Malaysia which are Federal Constitution, Persons with Disabilities Act 2008, Education Act 1996 (Education Act), Education (Special Education) Regulations 1997 (Special Education Regulations) and Malaysian Plan of Action for People with Disabilities 2016-2022. Article 8 provides that "all persons are equal before the law and entitled to the equal protection of the law". Based on this provision, it can be concluded that 
children with disabilities are equal before the law and entitled to the same rights as other children. Article 12 of the Federal Constitution further provides " without prejudice to the generality of Article 8, there shall be no discrimination against any citizen on the grounds only of religion, race, descent or place of birth in the administration of any educational institution maintained by a public authority, and in particular, the admission of pupils or students or the payment of fees". Hence, by virtue of Article 12 of the Federal Constitution, children with disabilities should not be discriminated with respect to education.

Besides, according to Section 28 of the Persons with Disabilities Act 2008 "Persons with disabilities shall not be excluded from the general education system on the basis of disabilities, and children with disabilities shall not be excluded from pre-school, primary, secondary and higher education, on an equal basis with persons or children without disabilities, including vocational training and lifelong learning". This section conforms with Article 8 and Article 12 of the Federal Constitution in which children with disabilities should not be discriminated because of their disability status and must be treated equally with normal children in respect of education.

Furthermore, the right of children with disabilities in respect of their education also has been provided under the Education Act 1996 and its regulations. Based on Section 40 of the Education Act 1996 "The Minister shall provide special education in special schools established under paragraph 34(1)(b) or in such primary or secondary schools as the Minister deems expedient". Under this section, the minister if he thinks fit, may provide special education for children with disabilities in special schools or designated primary and secondary schools. According to Human Rights Commission of Malaysia (2015), children with disabilities who are "educable" are eligible to be admitted into Special Education Programme based on the Education (Special Education) Regulations 1997 and 2013.

In addition, the Malaysian Plan of Action for People with Disabilities 2016-2022 sets out the plans and strategies of the Malaysian Government in implementing the action plan for persons with disabilities in the future. Core Strategic 3 of the national plan aims to increase the access of persons with disabilities in respect of education through enhancing their access to a quality and inclusive education at all stages. (Rahim \& Samad, 2017) This shows that persons with disabilities including children with disabilities have been given right in respect of education in Malaysia.

Review of literature on education for children with special needs from Malaysia and abroad demonstrates two distinct concerns. Whilst Malaysia concentrates on the progress and development of special needs education and also the adequacy of the law and policy, international research more focuses, amongst others, on the importance of teachers' knowledge on the present law governing education for children with special needs on the premise that the rights of children with special needs in education are protected and fortified if the teachers and the school have good knowledge and awareness on the law governing special education. Following this, this paper aims to highlight the importance of teachers' knowledge and awareness in the law and policy governing special education in Malaysia to guarantee the rights of these children are protected. To achieve this aim, the extent of teachers' knowledge and awareness must be examined first, thus this is the objective of this paper/research. 
DEVELOPMENT

Vol. 10, No. 3, 2021, E-ISSN: 2226-6348 ㄷ 2021 HRMARS

\section{Research Methodology}

In pursuit of achieving the aim and objective of this research, it has adopted a mixed method which is a combination of qualitative and quantitative methods. For the qualitative method, secondary data was obtained from the statutes, books, journals and online articles.

For quantitative method, this tradition is strong in the field which involves the impact of the law on society (Mullane, 1998; Mechoulan, 2006). This research adopted a descriptive method. Descriptive research is a type of quantitative research that involves making careful descriptions of a phenomenon. (Singh, Fook, \& Sidhu, 2006). The researchers are interested to get the thoughts, perceptions and opinions of a population relating to the issue in question. It is to find out how the members of the population distribute themselves in the variables. The combination of methods involves the collection, analysis, and integration of qualitative and quantitative data in this study (Sharlene Nagy \& Hesse-Biber, 2010). The researchers have used the qualitative study to generate a specific set of theories and then tested out these generated ideas on a more representative population (QUAL - quan) (Hesse-Biber, 2010). For the purpose of data collection, questionnaires have been distributed randomly to 80 teachers in some primary and secondary schools in Selangor but the valid response was only 64. The objective of the questionnaire is to examine the legal knowledge and awareness of teachers towards the educational rights of children with special needs. The sample from the teachers' population has been identified by using convenience sampling. According to (Sekaran \& Bougie, 2009), this sampling involves whoever happens to be available in a particular setting and the elements involved do not have a known or predetermined chance of being selected as subjects. The questionnaire consists of three parts namely demographic characteristics, legal awareness and legal knowledge, and suggestions for the improvement of the special education system in Malaysia. The questionnaire consists of questions which are simple, direct and easy to understand.

\section{Analysis and Finding}

Demographic Characteristics

Below are the demographic characteristics of 64 respondents which include their age, gender, highest education and experience in teaching children with special needs.

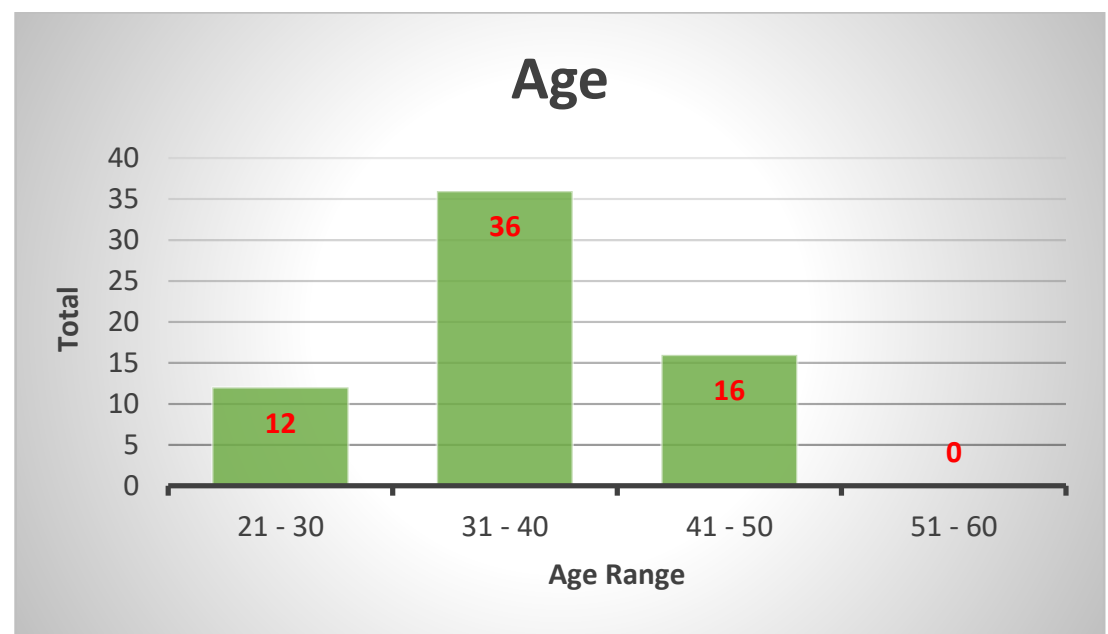

Figure 1.1.1: Age of the Respondents 

DEVELOPMENT

Vol. 10, No. 3, 2021, E-ISSN: 2226-6348 @ 2021 HRMARS

Figure 1.1.1 above shows the respondents' age. Most of the teachers who joined this study are aged between 31 to 40 years old with 36 respondents. There are 12 and 16 teachers who aged 21 to 30 years old and 41 to 50 years old, respectively.

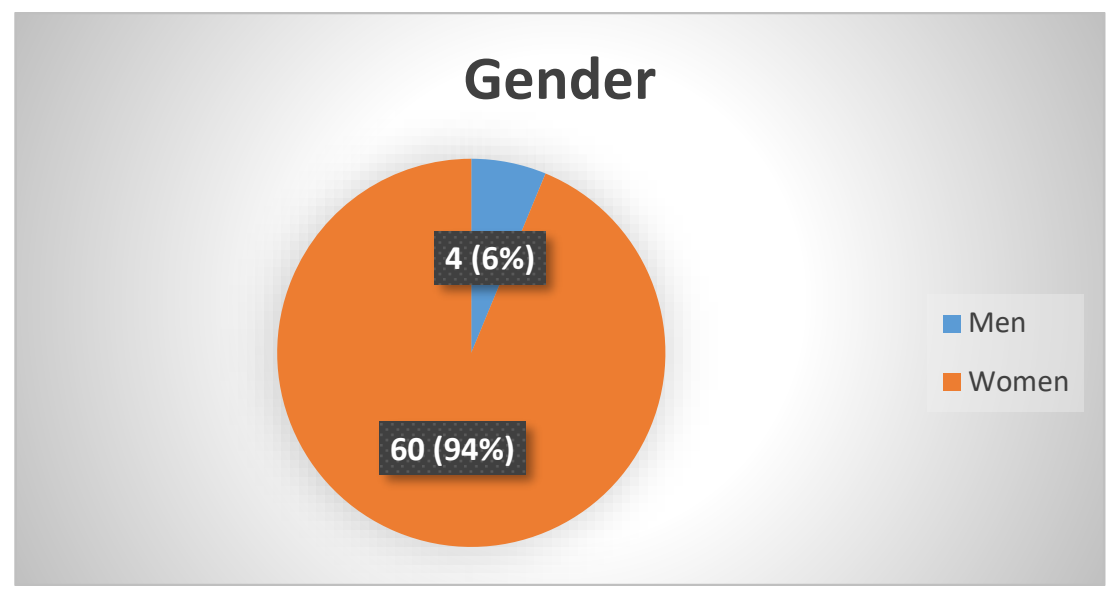

Figure 1.1.2: Gender of the Respondents

Gender of respondents involved in this is presented in Figure 1.1.2. Majority of the respondents are women which is 60 respondents while men respondents joined this study only 4.

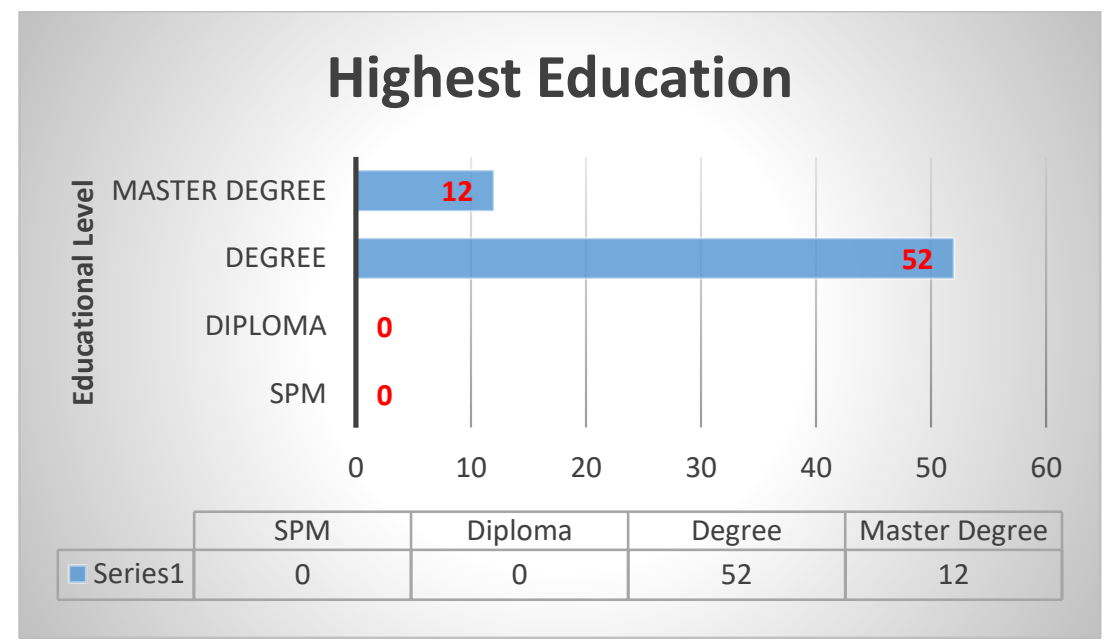

Figure 1.1.3: Respondents' Highest Level of Education

Figure 1.1.3 displays the highest level of education for the respondents who involved in this study. About 52 teachers or respondents are having degree qualification while the another 12 respondents are graduated in master degree. 


\section{Teaching Experience}

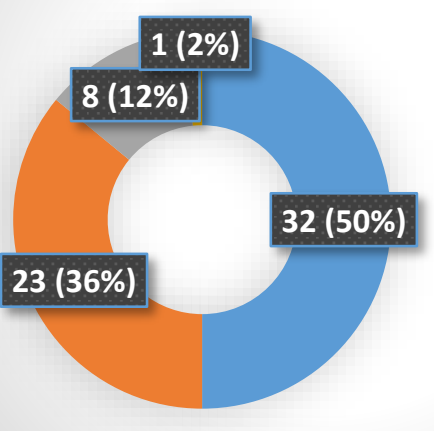

Below 5 years

- $6-10$

$11-15$

$16-20$

Figure 1.1.4: Respondents' Teaching Experience

The respondents' teaching experience can be viewed in Figure 1.1 .4 above. $50 \%$ of the respondents have been teaching students with special needs for less than 5 years and only a respondent has been served as teachers for students with special needs about 16 to 20 years. 1.2. Legal Knowledge and Awareness of the Teachers

Table 1.2.1: The Percentage of Answering Correct Answer

\begin{tabular}{|l|l|l|l|}
\hline & Question & $\begin{array}{l}\text { Correct } \\
\text { Answer }\end{array}$ & $\begin{array}{l}\text { Percentage } \\
\text { of } \\
\text { Correct } \\
\text { Answer }\end{array}$ \\
\hline 1 & $\begin{array}{l}\text { All persons are equal before the law and entitled to the equal } \\
\text { protection of the law. }\end{array}$ & True & 100 \\
\hline 2 & $\begin{array}{l}\text { Article 11 of the Federal Constitution emphasizes that there } \\
\text { shall be no discrimination in any matters including education, } \\
\text { against any Malaysian citizen on the grounds only of religion, } \\
\text { race, descent or place of birth. }\end{array}$ & False \\
\hline 3 & $\begin{array}{l}\text { According to the Education Act 1996, the Minister shall } \\
\text { provide special education in special schools or such primary } \\
\text { or secondary schools as the Minister deems expedient. }\end{array}$ & True & 100 \\
\hline 4 & $\begin{array}{l}\text { The Minister may by regulations prescribe the duration of } \\
\text { primary and secondary education suitable to the needs of a } \\
\text { pupil in receipt of special education. }\end{array}$ & True & 96 \\
\hline 5 & $\begin{array}{l}\text { The categories of pupils requiring special education and the } \\
\text { methods appropriate for the education of pupils in each } \\
\text { category of special schools are determined by the } \\
\text { Headmaster. }\end{array}$ & False \\
\hline 6 & $\begin{array}{l}\text { The duration for special education prescribed by the Minister } \\
\text { shall not be more than the minimum duration for primary or } \\
\text { secondary education, as the case may be, provided under the } \\
\text { Education Act 1996. }\end{array}$ & 50 \\
\hline
\end{tabular}




\begin{tabular}{|l|l|l|l|}
\hline 7 & $\begin{array}{l}\text { Persons with disabilities shall not be excluded from the } \\
\text { general education system on the basis of disabilities, and } \\
\text { children with disabilities shall not be excluded from pre- } \\
\text { school, primary, secondary and higher education, on an equal } \\
\text { basis with persons or children without disabilities, including } \\
\text { vocational training and lifelong learning. }\end{array}$ & 100 \\
\hline 8 & $\begin{array}{l}\text { The Government and private educational providers shall, in } \\
\text { order to enable persons and children with disabilities to } \\
\text { pursue education, provide reasonable accommodation } \\
\text { suitable with the requirements of persons and children with } \\
\text { disabilities in terms of, among others, infrastructure, } \\
\text { equipment and teaching materials, teaching methods, } \\
\text { curricula and other forms of support that meet the diverse } \\
\text { needs of persons or children with disabilities. }\end{array}$ & 100 \\
\hline 9 & $\begin{array}{l}\text { According to Persons with Disabilities Act 2010, the } \\
\text { government and private educational providers shall take } \\
\text { appropriate steps and measures to enable persons and } \\
\text { children with disabilities to learn life and social development } \\
\text { skills to facilitate their full and equal participation in } \\
\text { education. }\end{array}$ & False \\
\hline 10 & $\begin{array}{l}\text { All types of facilities should be available to facilitate the } \\
\text { learning of Braille, alternative script, augmentative and } \\
\text { alternative modes, means and formats of communication } \\
\text { and orientation and mobility skills, and facilitating peer } \\
\text { support and mentoring. }\end{array}$ & 4 \\
\hline
\end{tabular}

Table 1.2.1 above shows the result the percentage of the correct answer from collected data. If we can see, most of the respondents answered the questions correctly except for 3 questions which are Question 2, 6 and 9. All these questions were used to measure their legal knowledge.

Table 1.2.2: The Level of Legal Knowledge and Awareness

\begin{tabular}{|l|l|}
\hline Mean Percentage of Correct Answer & Level \\
\hline $0-33.33$ & Low \\
\hline $33.34-66.67$ & Moderate \\
\hline $66.68-100$ & High \\
\hline
\end{tabular}

To measure the level of legal knowledge and awareness of the respondents, the mean percentage of the correct answer has been divided by 3 and categorized into three levels as presented in Table 1.2.2.

Table 1.2.3: The Mean Percentage of Legal Knowledge and Awareness

\begin{tabular}{|l|l|l|}
\hline Variable & Mean Percentage of Correct Answer & Level \\
\hline Knowledge & $59.25 \%$ & Moderate \\
\hline Awareness & $100 \%$ & High \\
\hline
\end{tabular}


The mean percentage of legal knowledge and awareness are $59.25 \%$ and $100 \%$, respectively. The mean percentage of $59.25 \%$ for legal knowledge reveals that the teachers only have moderate knowledge about the educational rights of children with special needs. Even though their knowledge at a moderate level, but they have a high awareness on the educational rights of children with special needs since the mean percentage of the correct answer is $100 \%$.

\section{Conclusion and Recommendations}

It is undeniable that there are many challenges in ensuring the right of children with special needs in education is upheld. Based on the research conducted, it can be concluded that the level of knowledge of the teachers regarding on educational rights of children with special needs is moderate while their level of awareness of the students' educational rights is high. Therefore, a few recommendations have been made to tackle the issue of the teachers' knowledge on the educational right of children with special needs. Among the recommendations are:

a) The government should provide legal knowledge on the educational rights of children with special needs to citizens especially teachers through programmes or courses.

b) The government also must ensure the citizens, especially teachers, are aware of the educational rights of children with special needs through campaign or mass media.

c) Legal knowledge and awareness among teachers and stakeholders should be fortified and enhanced to protect and uphold the educational rights of the school children with special needs.

d) Assistive Devices: Some schools lack access to basic equipment such as brailing machines and computers with appropriate software for use by visually impaired persons. There are huge challenges with the adaptation and brailing of some standardized examination and test papers and other devices which are appropriate to deal with the disabled children. It is difficult to handle situations like this when there are lacking in devices when those are needed the most. Supposedly stakeholders take charge of these situations when needed. (https://www.right-to-education.org/es/node/412)

\section{References}

Abdul Nasir, M. N., Efendi E. A. N. A. (2016). Special education for children with disabilities in Malaysia: Progress and obstacles, Malaysian Journal of Society and Space, 12 (10), 78 87.

Abdul Rahim, A., Abd Samad, N. A., Said, I., \& Seman, W. M. A. (2017). Malaysian Plan of Action for People with Disabilities 2016-2022: Way Forward. UIA 2017 Seoul World Architects Congress, 2.

Adnan, A. H., Hafiz, I. A. (2001). A Disabling Education: The Case of Disabled Learners in Malaysia. Disability \& Society, 16 (5), 655-669.

Cheng, S. C., \& Loh, S. C. (2011). Perceptions of Pre-School Special Educators and Parents towards Learning through Play. Journal of Special Education, 1 (1), 23-36.

Disabled children, The situation of differently-abled children. https://www.humanium.org/en/disabled-children/accessed 12.2.2019 Education Act 1996

Farrell, P. (2001). Current issues in special needs: Special education in the last twenty years: have things really got better? British Journal of Special Education, 28 (1), 3-9. 
DEVELOPMENT

Vol. 10, No. 3, 2021, E-ISSN: 2226-6348 @ 2021 HRMARS

Mullane, G. R. (1998). Evidence of Social Science Research: Law, Practice and Options in the Family Court of Australia, Australian Law Journal, 72, 434.

Glidewell, C. (2012). A survey of teacher knowledge and understanding of special education law. Curriculum and Instruction, Undergraduate Honors Theses. 7. http://scholarworks.uark.edu/cieduht/7

Heward, L. W. (2000). Exceptional Children: an introduction to special education, (sixth edition). Upper Saddle River, NJ: Prentice-Hall.

Human Rights Commission of Malaysia. (2015). The Right to Education for Children with Learning Disabilities: Focusing on Primary Education. Kuala Lumpur: Human Rights Commission of Malaysia.

Ismail, N., Zaman, H. B. (2011). Self-Voicing Browser Enhancing Accessibility in Virtual Learning Environment for the Blind. Journal of Special Education, 1 (1), 72-85.

Kang, P.P., Saad, S. (2011) Dyslexic: Self-Intervention. Journal of Special Education, 1 (1), 6-22.

Kurniawati, A. D. (2017). Evaluating the effect of a teacher training programme on the primary teachers' attitudes, knowledge and teaching strategies regarding special educational needs. An International Journal of Experimental Educational Psychology, 37(3), 287-297.

Lee, L. W., Low, H. M. (2014). The Evolution of Special Education in Malaysia. British Journal of Special Education, 41 (1), 42-58.

Loke, J. D., Zakaria, A. R., \& Lau, P. L. (2013). Pendekatan Terapi Lukisan dalam Kalangan Kanak-kanak Autisme. Journal of Special Education, 3 (1), 92-108.

Maiese, M. (2003). Distributive Justice: Beyond Intractability. Eds. Guy Burgess and Heidi Burgess. Conflict Information Consortium, University of Colorado, Boulder.

Malaysia Education Blueprint 2013-2025 (Preschool to Post-Secondary Education), Ministry of Education Malaysia

Malaysian Federal Constitution

Mazlan, N. H., \& Daud, S. M. (2011). Electronic Signing Storybook (CODREAD) for Deaf Students. Journal of Special Education, 1 (1), 63-71.

Ministry of Education (MOE). (2013a). Garis Panduan Program Pendidikan Inklusif Murid Berkeperluan Khas (Edisi Percubaan). Bahagian Pendidikan Khas, Putrajaya: Malaysian Ministry of Education.

Mottan, K. (2015). A Pilot Study into an Integrated Special Needs Programme using the CIPP Model (M2015). International Journal of Assessment and Evaluation in Education, 5, 5766.

O'Connor, E. A., Yasik, A. E., \& Horner, S. L. (2016). Teachers' Knowledge of Special Education Laws: What Do They Know? Insights into Learning Disabilities, 13(1), 7-18.

Omar, S. R., \& Sulaiman, A. Z. (2018). Implementation of Inclusive Education Programme for Special Education Need Students with Learning Disabilities in Malaysia. International Journal of Civilizational Studies and Human Sciences, 1(4), 85-95.

Persons with Disabilities Act 2008

Rawls, J. Theory of Justice, The Belknap Press of Harvard University Press, Cambridge, Massachusetts.

Baqutayan, S. M., Khalil, S. A., Baharum N. A., \& Abu Hassan, N. (2016). Special Education for Children with Disabilities: A Review of the Current Policy and Practice in Malaysia, Journal of Advanced Review on Scientific Research, 25(1), 1-10.

Shakespeare, T. (2010). The Social Model of Disability. The Disability Studies Reader. Ed. Lennard J. Davis. New York: Routledge. 
Hesse-Biber, S. N. (2010). Mixed Methods Research: Merging Theory With Practice. The Guilford Press New York.

Teng, K. Y. (2016). Contributions of Inclusive Education Programme, Teachers' Attitudes and Efficacy on Social Skills Among Students with Autism Spectrum Disorder. Unpublished doctoral dissertation, Universiti Teknologi Malaysia, Malaysia.

Turnbull, H. R., \& Turnbull, A. P. (1998). Free Appropriate Public Education: The Law and Children with Disabilities. Fifth Edition. Love Publishing Company.

Eni, U. U., \& Arit, M. (2016). Knowledge of Education Law and Human Rights Violations among Secondary School Personnel in Nigeria, International Journal of Education, Learning and Development, 4 (5), 38-47.

Sekaran, U., \& Bougie, R. (1992). Research Methods for Business: a Skill Building Approach. U.S.: John Wiley \& Sons.

UNESCO. (1994) The Salamanca Statement and Framework for Action on Special Needs Education.

World Conference on Special Needs Education: Access and Quality Salamanca, Spain, 7-10 June 1994

Zainol, M., Majid, R. A. (2013). Pelaksanaan Terapi Carakerja Demi Penguasaan Kemahiran Motor Halus Murid Bekeperluan Khas di Sekolah. Journal of Special Education, 3 (1), 8191.

Zainon, H., \& Ghani, M. Z. (2012). Tekanan Emosi Guru Pendidikan Khas di Sekolah Integrasi. Journal of Special Education, 2 (1), 138-149.

\section{Acknowledgment}

Thank you to the Ministry of Higher Education (MOHE) and Research Management Centre (RMC) Universiti Teknologi Mara (UiTM) for the financial supports through FRGS RACER $1 / 2019$. 